\title{
Two new Sordariomycetes records from forest soils in Thailand
}

\author{
Yasanthika WAE ${ }^{1,2,6}$, Wanasinghe $\mathrm{DN}^{3,4,5}$, Karunarathna $\mathrm{SC}^{3,4,5}$, Bhat $\mathrm{DJ}^{7}$, \\ Samarakoon SMBC ${ }^{1,2}$, Ren GC ${ }^{1,3}$, Monkai $\mathbf{J}^{1}$, Mortimer PE ${ }^{3,5}$ and Hyde $\mathrm{KD}^{1,2,6^{*}}$
}

\author{
${ }^{1}$ Center of Excellence in Fungal Research, Mae Fah Luang University, Chiang Rai, 57100, Thailand \\ ${ }^{2}$ School of Science, Mae Fah Luang University, Chiang Rai, 57100, Thailand \\ ${ }^{3}$ CAS Key Laboratory for Plant Biodiversity and Biogeography of East Asia (KLPB), Kunming Institute of Botany, \\ Chinese Academy of Science, Kunming 650201, Yunnan, People's Republic of China \\ ${ }^{4}$ World Agroforestry Centre, East and Central Asia, 132 Lanhei Road, Kunming 650201, Yunnan, People's Republic of \\ China \\ ${ }^{5}$ Centre for Mountain Futures (CMF), Kunming Institute of Botany, Kunming 650201, Yunnan, People's Republic of \\ China \\ ${ }^{6}$ Innovative Institute of Plant Health, Zhongkai University of Agriculture and Engineering, Guang Dong Province, \\ People's Republic of China \\ ${ }^{7}$ Formerly, Department of Botany, Goa University, Goa, India; House No. 128/1-J, Azad Co-Op Housing Society, \\ Curca, P.O. Goa Velha-403108, India
}

Yasanthika WAE, Wanasinghe DN, Karunarathna SC, Bhat DJ, Samarakoon SMBC, Ren GC, Monkai J, Mortimer PE, Hyde KD 2020 - Two new Sordariomycetes records from forest soils in Thailand. Asian Journal of Mycology 3(1), 456-471, Doi 10.5943/ajom/3/1/16

\begin{abstract}
Forest soils contain relatively high levels of fungal diversity compared to other soil types and are primarily comprised of pathogens, saprobes or mutualists. This study was conducted to investigate the fungal diversity of mixed deciduous forest soils in Thailand. Fungi were isolated using a dilution plate method and are illustrated, described and subjected to combined phylogenetic analyses (maximum likelihood and Bayesian analyses). We herewith report Beltraniella fertilis and Stachybotrys subcylindrospora for the first time from mixed deciduous forest soils of northern Thailand.
\end{abstract}

Key words - Beltraniella fertilis - dilution plate method - phylogeny - soil fungi - Stachybotrys subcylindrospora

\section{Introduction}

Soil is a highly diversified and unique habitat for various types of microorganisms (Bridge \& Spooner 2001, Pangging et al. 2019, Wei et al. 2020). A large array of taxonomic and functional groups of fungi are found in soil ecosystems. These fungal groups have saprobic, pathogenic and mutualistic (mycorrhizal) nutritional modes, all of which play major roles in plant growth and nutrient cycling in forest ecosystems (Taylor \& Sinsabaugh 2015, Shi et al. 2019). Besides Basidiomycetes, soil fungal taxa largely belong to Sordariomycetes, which are widely distributed across Thailand forest soils (Tedersoo et al. 2014, Amma et al. 2018). In our study, we report two species of Sordariomycetes, belonging to Beltraniaceae and Stachybotryaceae, from mixed deciduous forest (dominated by Dipterocarpaceae) soils in northern Thailand.

Beltraniella was established by Subramanian (1952) with B. odinae as the type species. Most species of Beltraniella were reported as asexual morphs. Pseudomassaria carolinensis (sexual 
morph) was previously linked to B. portoricensis (asexual morph) based on morphological support by Hodges \& Barr (1971). Subsequently, B. carolinensis was proposed as a new combination with $P$. carolinensis, supported by the phylogenetic analyses of Jaklitsch et al. (2016). Castañeda-Ruiz et al. (1996) provided a key for Beltraniella species. Shirouzu et al. (2010) provided a synopsis for all accepted species in Beltraniella. The genus is currently accommodated in Beltraniaceae (Xylariales, Xylariomycetidae) with 28 species epithets from various hosts and habitats (i.e. fallen decomposing leaves, soil and submerged woods in freshwater) in tropical and subtropical regions of the world (Pirozynski 1963, Kirk 1981, Goh \& Hyde 1996, Sakayaroj et al. 2005, Duong et al. 2008, Lin et al. 2017a, b, Hyde et al. 2020, Index Fungorum 2020, Wijayawardene et al. 2020). Four species of Beltraniella (B. amoena, B. fertilis, B. japonica and B. portoricensis) have been identified, and recorded from Brazil (Gusmão et al. 2000, Marques et al. 2007, Magalhães et al. 2011). Magalhães et al. (2011) recorded B. fertilis and B. portoricensis on endemic plants of Atlantic forests. Dos Santos et al. (2014) also recorded B. botryospora and B. portoricensis associated with the leaf litter of Inga thibaudiana, Myrcia splendens and Pera glabrata along with the first report of B. botryospora from the Atlantic forest in Brazil. Beltraniella fertilis was erected by Heredia et al. (2002) as a saprobe on leaf litter from Mexico. Lin et al. (2017b) recorded the asexual morph of $B$. fertilis on leaf litter from Thailand.

Stachybotrys was introduced by Corda (1837) and typified with Stachybotrys atra (= S. chartarum) which belongs to Stachybotryaceae (Hypocreales, Sordariomycetes) (Bisby 1943, Seifert et al. 2011, Crous et al. 2014). Memnoniella and Stachybotrys were initially identified as two distinct genera in Stachybotryaceae (Bisby 1945, Jong \& Davis 1976). Lombard et al. (2016) supported this using multi-locus sequence analysis and presented the genera Memnoniella and Stachybotrys as well-supported distinct clades in the phylogenetic tree. However, Wang et al. (2015) suggested Stachybotrys as a synonym of Memnoniella based on morphological and phylogenetic similarities. Pinruan et al. (2004) provided a key for Stachybotrys that includes 50 species. Stachybotrys are found on damp papers, cotton, linen, soil, litter and other indoor environments as saprobes or pathogens (Ellis 1971, 1976, Whitton et al. 2001, Thongkantha et al. 2008, Jie et al. 2013, Wang et al. 2015). Most Stachybotrys species have been described from asexual morphs, and only $S$. oleronensis is described as the sexual morph with morpho-molecular support (Lechat et al. 2013, Crous et al. 2014). Recently, Melanopsamma and Ornatispora were linked as the sexual morphs of Stachybotrys (Lechat et al. 2013, Wang et al. 2015). Stachybotrys chartarum is common in soil and cellulose-based building materials (Wang et al. 2015). Wu \& Zhang (2010) isolated S. jiangziensis and S. xigazenensis from forest soil in China. Furthermore, Jie et al. (2013) introduced $S$. subcylindrospora from forest soils in China.

Beltraniella has mainly been recorded from plant litter whereas some species of Stachybotrys reported from soils (Lin et al. 2016, 2017a, b, Lee et al. 2019, Hyde et al. 2020). Most of these species exhibit a saprobic life mode while a few species are known to be plant pathogens (Wang et al. 2015, Lin et al. 2017a, b, Hyde et al. 2020). Soil fungal communities are poorly investigated using morpho-molecular analyses (Wu et al. 2013, Shi et al. 2019). Compared to other regions of East Asia, numerous studies relating to soil fungi have been conducted in China (Yang \& Insam 1991, Wu et al. 2013, Shi et al. 2019). However, studies on taxonomic diversity, molecular phylogeny, chemistry and geographic distribution of soil-inhabiting fungi in Thailand are still limited (Amma et al. 2018). Thus, it is important to improve our knowledge of fungi and fungal communities from soils in Thailand as this knowledge could contribute towards an improved scientific understanding of fungi in tropical soils, improved forest management systems and enhanced agricultural practices (Amma et al. 2018, Khuna et al. 2019). In this study, we carried out an investigation of soil-inhabiting microfungi in Thailand. We present the first report of Beltraniella fertilis from mixed deciduous forest soils and the first country record of Stachybotrys subcylindrospora from soils in northern Thailand. 


\section{Sample collection, fungal isolation and morphological characterization}

Soil samples were collected from a mixed deciduous forest (dominated by Dipterocarpaceae) in Chiang Mai Province, Thailand during the dry season (March 2019). The samples were taken to the laboratory using zip-lock plastic bags within an icebox and kept in cold storage at $4^{\circ} \mathrm{C}$ until the isolation process started. The soil dilution plate method was used to isolate soil fungal strains (Aziz \& Zainol 2018, Lee et al. 2019). Ten grams of soil was dissolved in $100 \mathrm{~mL}$ of sterilized distilled water, and the sample was shaken thoroughly. One milliliter of the initial solution was transferred to a vial containing $9 \mathrm{~mL}$ of sterilized distilled water and thoroughly mixed. One milliliter of the diluted solution taken from the second vial was transferred to a third vial containing $9 \mathrm{~mL}$ of sterilized distilled water. Similarly, the soil sample was diluted six times (with sterilized distilled water) from $10^{-1}$ until $10^{-6}$. From each dilution, $0.1 \mathrm{~mL}$ of the solution was transferred into a Petri dish containing, antibiotic treated-sterilized PDA (Potato Dextrose Agar) medium and uniformly spread on the surface of the medium using a sterilized glass spreader. The plates were sealed and incubated at $25^{\circ} \mathrm{C}$ for $2-3$ days, until colony formation. As the colonies appeared, hyphal tips from each colony were transferred into fresh PDA plates to get pure fungal culture. The pure cultures were incubated at $25^{\circ} \mathrm{C}$ to facilitate sporulation. Conidial structures with mycelium were removed with a needle and placed in a drop of distilled water on a slide for morphological study. Photomicrographs of fungal structures were captured using an OLYMPUS SZ61 compound microscope, and images were recorded with a Canon EOS 600D digital camera mounted on a Nikon ECLIPSE 80i compound microscope. All measurements were made using the Tarosoft (R) Image Frame Work program. Photo-plates were made with Adobe Photoshop CS6 Extended version 13.0.1 (Adobe Systems, USA). Living cultures were deposited at Mae Fah Luang University Culture Collection (MFLUCC), Chiang Rai, Thailand. Dried culture specimens were deposited at Mae Fah Luang University Herbarium (Herb. MFLU). Faces of Fungi numbers were registered as described in Jayasiri et al. (2015).

\section{DNA extraction, PCR amplification and sequencing}

Fungal isolates were grown on PDA for six weeks at $25^{\circ} \mathrm{C}$, and total genomic DNA were extracted from 50 to $100 \mathrm{mg}$ of axenic mycelium from the growing cultures. Mycelium was ground to a fine powder with liquid nitrogen, and fungal DNA was extracted using the Biospin Fungus Genomic DNA Extraction Kit (BioFlux ${ }^{\circledR}$ ) (Hangzhou, P. R. China) according to the manufacturers' instructions. Polymerase chain reactions (PCR) conducted to amplify the internal transcribed spacer region of ribosomal DNA (ITS) and large subunit nuclear ribosomal DNA region (LSU) by using ITS5/ITS4 (White et al. 1990), and LR0R/LR5 primers, respectively (Vilgalys \& Hester 1990). Other protein-coding gene regions were amplified as follows: the $\beta$ tubulin (tub2) gene region amplified using primers Bt2a and Bt2b (Glass \& Donaldson 1995), and calmodulin (cmdA) using primers CAL-228F (Carbone \& Kohn 1999) and CAL2Rd (Groenewald et al. 2005). PCR amplification process was conducted in a $25 \mu \mathrm{L}$ PCR mixture containing $12.5 \mu \mathrm{L}$ of $2 \times$ Power Taq PCR MasterMix (a premixed ready-to-use solution, composed of $0.1 \mathrm{Units} / \mu \mathrm{L}$ Taq DNA Polymerase, $500 \mu \mathrm{M}$ dNTP Mixture each (dATP, dCTP, dGTP, dTTP), $20 \mathrm{mM}$ TrisHCl pH 8.3, $100 \mathrm{Mm} \mathrm{KCl}, 3 \mathrm{mM} \mathrm{MgCl} 2$, stabilizer and enhancer $), 1 \mu \mathrm{L}$ of each primer $(10 \mu \mathrm{M}), 2 \mu \mathrm{L}$ genomic DNA extract and $8.5 \mu \mathrm{L}$ double distilled water. The PCR thermal cycle for the amplification of LSU and ITS regions was programmed initially at $94^{\circ} \mathrm{C}$ for 3 mins., followed by 35 cycles of denaturation at $94^{\circ} \mathrm{C}$ for $30 \mathrm{~s}$, annealing at $55^{\circ} \mathrm{C}$ for $50 \mathrm{~s}$, elongation at $72^{\circ} \mathrm{C}$ for $1 \mathrm{~min}$., and a final extension at $72^{\circ} \mathrm{C}$ for $10 \mathrm{~min}$ ( $\mathrm{Lin}$ et al. 2016, 2017b). The PCR conditions for the amplification of the cmdA was initiated at $94^{\circ} \mathrm{C}$ for $5 \mathrm{~min}$ and 40 cycles were executed. Each cycle consists of denaturation at $94^{\circ} \mathrm{C}$ for $30 \mathrm{~s}$, annealing at $52^{\circ} \mathrm{C}$ for $30 \mathrm{~s}$, and elongation at $72^{\circ} \mathrm{C}$ for 30 s. A final elongation was at $72^{\circ} \mathrm{C}$ for $7 \mathrm{~min}$. (Groenewald et al. 2005). Amplification of the $\beta$ tubulin region started at $94^{\circ} \mathrm{C}$ for $1 \mathrm{~min}$ and the temperature was reduced to around $58-68^{\circ} \mathrm{C}$ for 1 min, and later increased to $72^{\circ} \mathrm{C}$ for $1 \mathrm{~min}$. This process was repeated for 32 cycles under the above 
conditions, and 5-10s of extension time was maintained in each cycle (Glass \& Donaldson 1995). All PCR products were visualized using an ethidium bromide $(\mathrm{EtBr})$ staining on 1.2\% agarose gels. Successful PCR products were sent for the sequencing at Qingke Company, Kunming City, Yunnan Province, P. R. China.

\section{Sequence alignment}

Obtained sequences were subjected to a BLAST search in GenBank (https://blast.ncbi.nlm.nih.gov/Blast.cgi). BLAST search results and initial morphological studies supported that our isolates belonged to Beltraniella and Stachybotrys. Additional sequence data, based on previously published material, were obtained from GenBank (Table 1) (Jie et al. 2013, Crous et al. 2014, Lin et al. 2016, Lombard et al. 2016, Lin et al. 2017b, Hyde et al. 2020). The single gene and multigene alignments were automatically done by MAFFT v. 7.036 (http://mafft.cbrc.jp/alignment/server/index.html, Katoh et al. 2002) using the default settings and later refined where necessary, using BioEdit v. 7.0.5.2 (Hall 1999).

Table 1 Taxa used in the phylogenetic analyses with the corresponding GenBank accession numbers. Type strains are indicated as superscript $\mathrm{T}$ and newly generated strains are indicated in bold

\begin{tabular}{|c|c|c|c|c|c|}
\hline \multirow[t]{2}{*}{ Species } & \multirow[t]{2}{*}{ Strain Number } & \multicolumn{4}{|c|}{ Gene bank Accession number } \\
\hline & & cmdA & ITS & LSU & tub2 \\
\hline Achroiostachys betulicola & CBS 136397 & KU845772 & KU845792 & -- & KU845753 \\
\hline A. humicola & CBS 868.73 & KU845779 & KU845799 & -- & KU845760 \\
\hline Alfaria caricicola & CBS $113567^{\mathrm{T}}$ & KU845976 & KU845983 & -- & KU846014 \\
\hline Al. ossiformis & CBS 324.54 & KU845977 & KU845984 & -- & KU846015 \\
\hline Amphisphaeria flava & $\begin{array}{l}\text { MFLUCC 18- } \\
0361^{\mathrm{T}}\end{array}$ & -- & NR-168782 & NG-06858 & -- \\
\hline Am. sorbi & $\begin{array}{l}\text { MFLUCC 13- } \\
0721^{\mathrm{T}}\end{array}$ & -- & NR-153531 & KP744475 & -- \\
\hline $\begin{array}{l}\text { Beltrania } \\
\text { pseudorhombica }\end{array}$ & CPC 23656 & -- & KJ869158 & KJ869215 & -- \\
\hline B. rhombica & CPC 27482 & -- & KX519521 & KX519515 & -- \\
\hline Beltraniella acaciae & CPC $29498^{\mathrm{T}}$ & -- & NR-147685 & NG-066374 & -- \\
\hline Be. brevis & DS 2--23 & -- & MN252876 & MN252883 & -- \\
\hline Be. brevis & DS 2--21 & -- & MN252877 & MN252884 & -- \\
\hline Be. carolinensis & 9502 (IFO) & -- & - & DQ810233 & -- \\
\hline Be. endiandrae & CBS $137976^{\mathrm{T}}$ & -- & NR-148073 & NG-058665 & -- \\
\hline Be.fertilis & MFLUCC 17-2138 & -- & MF580248 & MF580255 & -- \\
\hline Be.fertilis & MFLUCC 19-0487 & -- & MT215489 & MT215539 & -- \\
\hline Be.fertilis & MFLUCC 17-2136 & -- & MF580246 & MF580253 & -- \\
\hline Be.fertilis & MFLUCC 17-2137 & -- & MF580247 & MF580254 & -- \\
\hline Be.fertilis & MFLUCC 20-0119 & -- & MT835158 & MT835156 & -- \\
\hline Be. humicola & CBS 203.64 & -- & MH858416 & MH870044 & -- \\
\hline Be. pandanicola & $\begin{array}{l}\text { MFLUCC 18- } \\
0121^{\mathrm{T}}\end{array}$ & -- & MH275049 & MH260281 & -- \\
\hline Be.portoricensis & NFCCI 3993 & -- & KX519516 & KX519522 & -- \\
\hline Be.portoricensis & CBS 856.70 & -- & MH859981 & MH871777 & -- \\
\hline Be. pseudoportoricensis & CBS $145547^{\mathrm{T}}$ & -- & NR-165552 & NG-067875 & -- \\
\hline Be. ramosiphora & LCG 10-2 & -- & MG717500 & MG717502 & -- \\
\hline Be. thailandica & $\begin{array}{l}\text { MFLUCC 16- } \\
0377^{\mathrm{T}}\end{array}$ & -- & NR-168175 & NG-068824 & -- \\
\hline $\begin{array}{l}\text { Beltraniopsis } \\
\text { longiconidiophora }\end{array}$ & $\begin{array}{l}\text { MFLUCC 17- } \\
2139^{\mathrm{T}}\end{array}$ & -- & NR-158353 & NG-066200 & -- \\
\hline Be. neolitseae & CBS 137974 & -- & NR-148072 & NG-058664 & -- \\
\hline Brevistachys globosa & CBS 397.73 & KU846023 & KU846037 & -- & KU846100 \\
\hline
\end{tabular}


Table 1 Continued.

\begin{tabular}{|c|c|c|c|c|c|}
\hline \multirow[t]{2}{*}{ Species } & \multirow[t]{2}{*}{ Strain Number } & \multicolumn{4}{|c|}{ Gene bank Accession number } \\
\hline & & cmdA & ITS & LSU & tub2 \\
\hline Be. lateralis & CBS $141058^{\mathrm{T}}$ & KU846027 & KU846043 & -- & KU846106 \\
\hline Cymostachys coffeicola & CBS 252.76 & KU846035 & KU846052 & -- & KU846113 \\
\hline C. fabispora & CBS $136180^{\mathrm{T}}$ & KU846036 & KU846054 & -- & KU846114 \\
\hline Globobotrys & CBS $138872^{\mathrm{T}}$ & -- & KR476717 & -- & KR476794 \\
\hline sansevieriicola & & & & & \\
\hline $\begin{array}{l}\text { Grandibotrys } \\
\text { pseudotheobromae }\end{array}$ & CBS $136170^{\mathrm{T}}$ & -- & KU846135 & -- & KU846241 \\
\hline G. xylophila & CBS $136179^{\mathrm{T}}$ & KU846115 & KU846137 & -- & -- \\
\hline Hemibeltrania cinnamomi & NFCCI 3997 & -- & KX519517 & KX519523 & -- \\
\hline H. cinnamomi & MFLUCC 17-2141 & -- & MF580251 & MF580258 & -- \\
\hline $\begin{array}{l}\text { Melanopsamma } \\
\text { pomiformis }\end{array}$ & CBS 325.90 & KU846031 & KU846048 & -- & KU846111 \\
\hline M. xylophila & CBS 100343 & KU846034 & KU846051 & -- & -- \\
\hline $\begin{array}{l}\text { Memnoniella } \\
\text { brunneoconidiophora }\end{array}$ & CBS $136191^{\mathrm{T}}$ & KU846116 & KU846139 & -- & KU846244 \\
\hline Me. echinata & CBS 216.32 & KU846119 & KU846142 & -- & KU846245 \\
\hline Me. ellipsoidea & CBS 136199 & KU846127 & KU846150 & -- & KU846252 \\
\hline Me. humicola & CBS 136197 & KU846131 & KU846155 & -- & KU846256 \\
\hline Me. pseudonilagirica & CBS 136405 & KU846132 & KU846157 & -- & KU846257 \\
\hline $\begin{array}{l}\text { Parapleurotheciopsis } \\
\text { caespitosa }\end{array}$ & CBS 519.93 & -- & MH862437 & NG-066263 & -- \\
\hline P. inaequiseptata & MUCL 41089 & -- & EU040235 & EU040235 & -- \\
\hline Peethambara sundara & CBS 646.77 & -- & KU846471 & -- & KU846551 \\
\hline Porobeltraniella porosa & NFCCI 3995 & -- & KX519519 & KX519525 & -- \\
\hline Po. porosa & NFCCI 3996 & -- & KX519520 & KX519526 & -- \\
\hline Pseudobeltrania lauri & CPC $33589^{\mathrm{T}}$ & -- & NR-166309 & NG-068311 & -- \\
\hline Ps. ocoteae & CPC $26219^{\mathrm{T}}$ & -- & NR-138416 & NG-067305 & -- \\
\hline Sirastachys castanedae & CBS 164.97 & KU846553 & KU846658 & -- & KU847094 \\
\hline Stachybotrys aloeticola & CBS $137940^{\mathrm{T}}$ & KU846570 & KJ817888 & -- & KJ817886 \\
\hline S. aloeticola & CBS 137941 & KU846571 & KJ817889 & -- & KJ817887 \\
\hline S. chartarum & CBS 129.13 & -- & KM231858 & -- & KM232127 \\
\hline S. chartarum & CBS 177.42 & -- & KU846678 & -- & KU847114 \\
\hline S. chartarum & CBS 182.80 & -- & KU846679 & -- & KU847115 \\
\hline S. chlorohalonata & CBS 109283 & KU846622 & KU846728 & -- & KU847163 \\
\hline S. chlorohalonata & CBS 109285 & KU846623 & KU846729 & -- & KU847164 \\
\hline S. chlorohalonata & DAOMC 235557 & KU846644 & KU846751 & -- & KU847185 \\
\hline S. dolichophialis & DAOMC 227011 & KU846628 & KU846734 & -- & KU847169 \\
\hline S. limonispora & CBS 128809 & KU846629 & KU846735 & -- & KU847170 \\
\hline S. limonispora & CBS 136165 & KU846630 & KU846736 & -- & KU847171 \\
\hline S. microspore & ATCC 18852 & -- & AF081475 & -- & -- \\
\hline S. microspore & CBS 186.79 & KU846631 & KU846737 & -- & KU847172 \\
\hline S. phaeophialis & KAS 525 & KU846632 & KU846738 & -- & KU847173 \\
\hline S. reniformis & ATCC 18839 & -- & AF081476 & -- & -- \\
\hline S. reniformis & CBS 976.95 & KU846633 & KU846739 & -- & KU847174 \\
\hline S. reniformis & CBS 136198 & -- & KU846740 & -- & -- \\
\hline S. subcylindrospora & HGUP $0201^{\mathrm{T}}$ & -- & KC305354 & -- & -- \\
\hline S. subcylindrospora & MFLUCC 20-0120 & MT861049 & MT835159 & -- & MT861048 \\
\hline S. subsylvatica & CBS 126205 & KU846634 & KU846741 & -- & KU847175 \\
\hline $\begin{array}{l}\text { Striatobotrys } \\
\text { eucylindrospora }\end{array}$ & CBS $203.61^{\mathrm{T}}$ & KU846648 & KU846755 & -- & KU847189 \\
\hline $\begin{array}{l}\text { Subramaniomyces } \\
\text { podocarpi }\end{array}$ & CPC $32031^{\mathrm{T}}$ & -- & NR-156659 & NG-066201 & -- \\
\hline
\end{tabular}


Note: -- refers "no data in GenBank"

\section{Phylogenetic analyses}

Two phylogenetic analyses were conducted separately for Beltraniaceae and Stachybotryaceae to identify the taxonomic placements of our strains. Maximum likelihood (ML) trees were generated using the RAxML-HPC2 on XSEDE (8.2.8) (Stamatakis et al. 2008) in the CIPRES Science Gateway platform (Miller et al. 2010). For each tree, parameters were set including 1000 replicates with the $\mathrm{GTR}+\mathrm{I}+\mathrm{G}$ model of nucleotide substitution rates. Bayesian analyses were conducted with MrBayes v. 3.1.2 (Huelsenbeck \& Ronqvist 2001) to evaluate Posterior probabilities (PP) (Rannala \& Yang 1996, Zhaxybayeva \& Gogarten 2002) by Markov Chain Monte Carlo sampling (BMCMC). In each analysis, two parallel runs were conducted using the default settings with the following adjustments: Six simultaneous Markov chains run for $2,000,000$ generations, trees were sampled at every $100^{\text {th }}$ generation, and 20,000 trees were obtained. The first 4,000 trees, representing the burn-in phase of the analyses were discarded. The remaining 16,000 trees were used to calculate the PP in the majority rule consensus tree. Phylograms were visualized with FigTree v1.4.0 program (Rambaut 2010) and reorganized in Microsoft power point.

\section{Results}

\section{Phylogenetic analysis of Beltraniaceae}

The tree inferred from a RAxML analysis belonging to Beltraniaceae genera (Fig. 1). The combined LSU and ITS alignment comprised 30 strains of Beltraniaceae and the outgroup comprised two taxa, Amphisphaeria flava (MFLUCC 18-0361) and A. sorbi (MFLUCC 13-0721). Combined alignment as well as the individual alignments were analyzed. A best scoring RAxML tree (Fig. 1) has a final ML optimization likelihood value of -4404.133370 . The matrix had 276 distinct alignment patterns, with $6.41 \%$ of undetermined characters or gaps. Estimated base frequencies were as follows; $\mathrm{A}=0.252948, \mathrm{C}=0.211572, \mathrm{G}=0.267559, \mathrm{~T}=0.267921$; substitution rates $\mathrm{AC}=1.018207, \mathrm{AG}=2.648344, \mathrm{AT}=1.48916, \mathrm{CG}=0.752809, \mathrm{CT}=6.303354$, GT $=1.00$; proportion of invariable sites $\mathrm{I}=0.672359$; gamma distribution shape parameter $\alpha=$ 0.612156. Both trees of ML and BYPP analyses were similar in topology at the generic relationships, which is in agreement with previous studies based on multi-gene phylogeny of Lin et al. (2017b) and Hyde et al. (2020). Our isolate Beltraniella fertilis (MFLUCC 20-0119) clustered with Beltraniella fertilis (MFLUCC 17-2136, MFLUCC 17-2137, MFLUCC 17-2138, MFLUCC 19-0487) with 82\% ML and 0.95 PP support.

\section{Phylogenetic analysis of Stachybotryaceae}

A best scoring RAxML tree resulted from the phylogenetic analyses of the combined calmodulin-ITS-tub2 alignment that comprised 40 strains of Strachybotryaceae and the outgroup taxon Peethambara sundara (CBS 646.77). The final ML optimization likelihood value of the best scoring RAxML tree (Fig. 2) is -15993.261619. The matrix had 870 distinct alignment patterns, with $24.41 \%$ of undetermined characters or gaps. Estimated base frequencies were as follows: $\mathrm{A}=$ $0.221214, \mathrm{C}=0.301303, \mathrm{G}=0.257589, \mathrm{~T}=0.219895$; substitution rates $\mathrm{AC}=1.284061, \mathrm{AG}=$ 3.421068, $\mathrm{AT}=1.422903, \mathrm{CG}=0.919545, \mathrm{CT}=4.917557, \mathrm{GT}=1.00$; proportion of invariable sites $\mathrm{I}=0.44495$; gamma distribution shape parameter $\alpha=1.165007$. Trees of ML and BYPP were similar in topology in generic relationships, which is in agreement with previous studies by Jie et al. (2013), Lombard et al. (2016) and Hyde et al. (2020). Our isolate (MFLUCC 20-0120) is grouped with the type strain Stachybotrys subcylindrospora (HGUP 0201) with strong statistical support $(\mathrm{ML}=98 \%, \mathrm{PP}=1.00)$. 


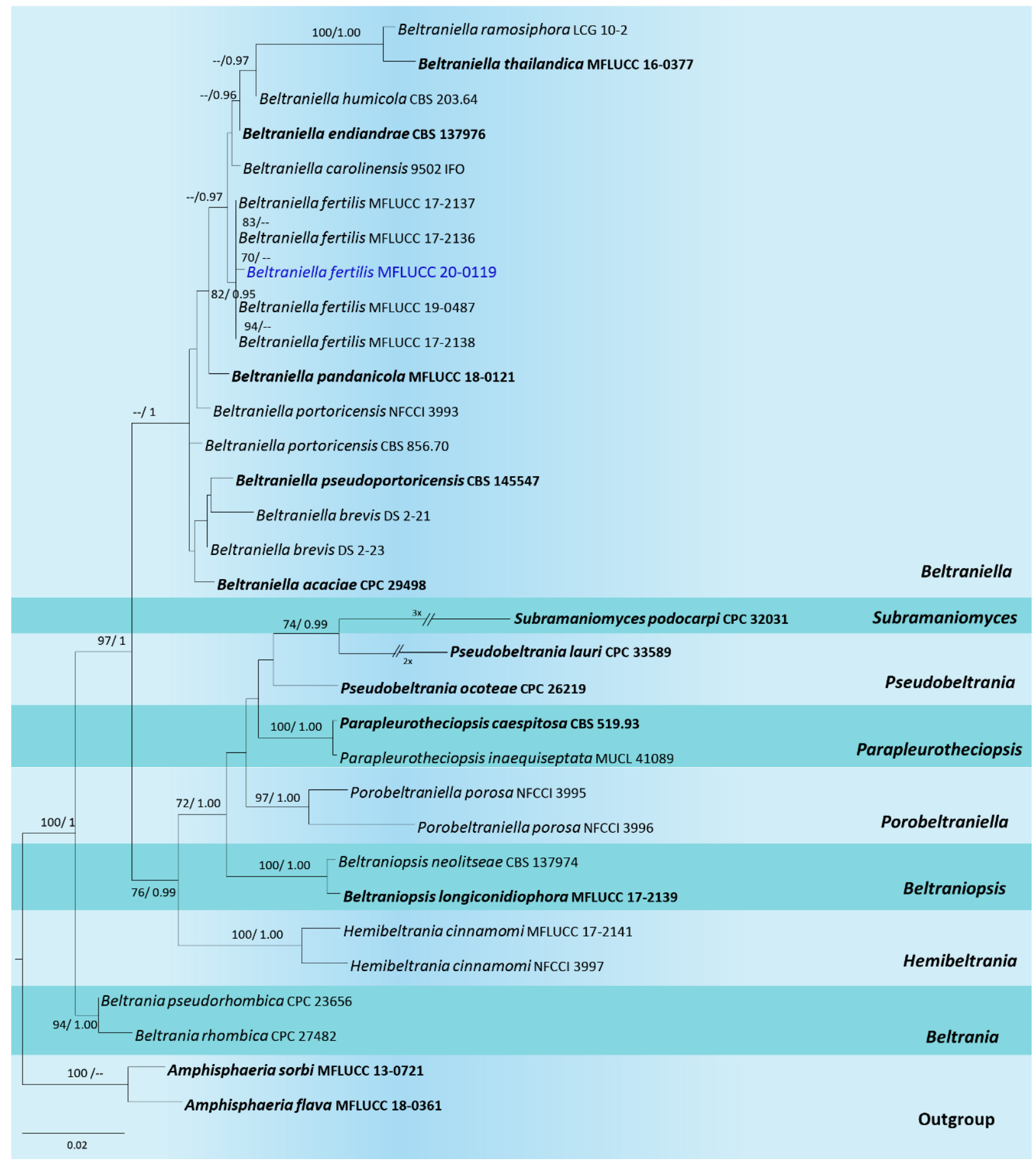

Fig. 1 - Maximum likelihood tree revealed by RAxML from an analysis of combined LSU-ITS matrix of Beltraniella, showing the phylogenetic position of Beltraniella fertilis (MFLUCC 200119). ML bootstrap supports equal to or greater than $60 \%$ and Bayesian posterior probabilities (PP) equal or greater than 0.95 are indicated above the nodes as (ML/ PP). The tree is rooted with Amphisphaeria flava (MFLUCC 18-0361) and A. sorbi (MFLUCC 13-0721). The ex-type strains are in bold and the new isolate of this study is in blue. The scale bar represents the expected number of nucleotide substitutions per site. 


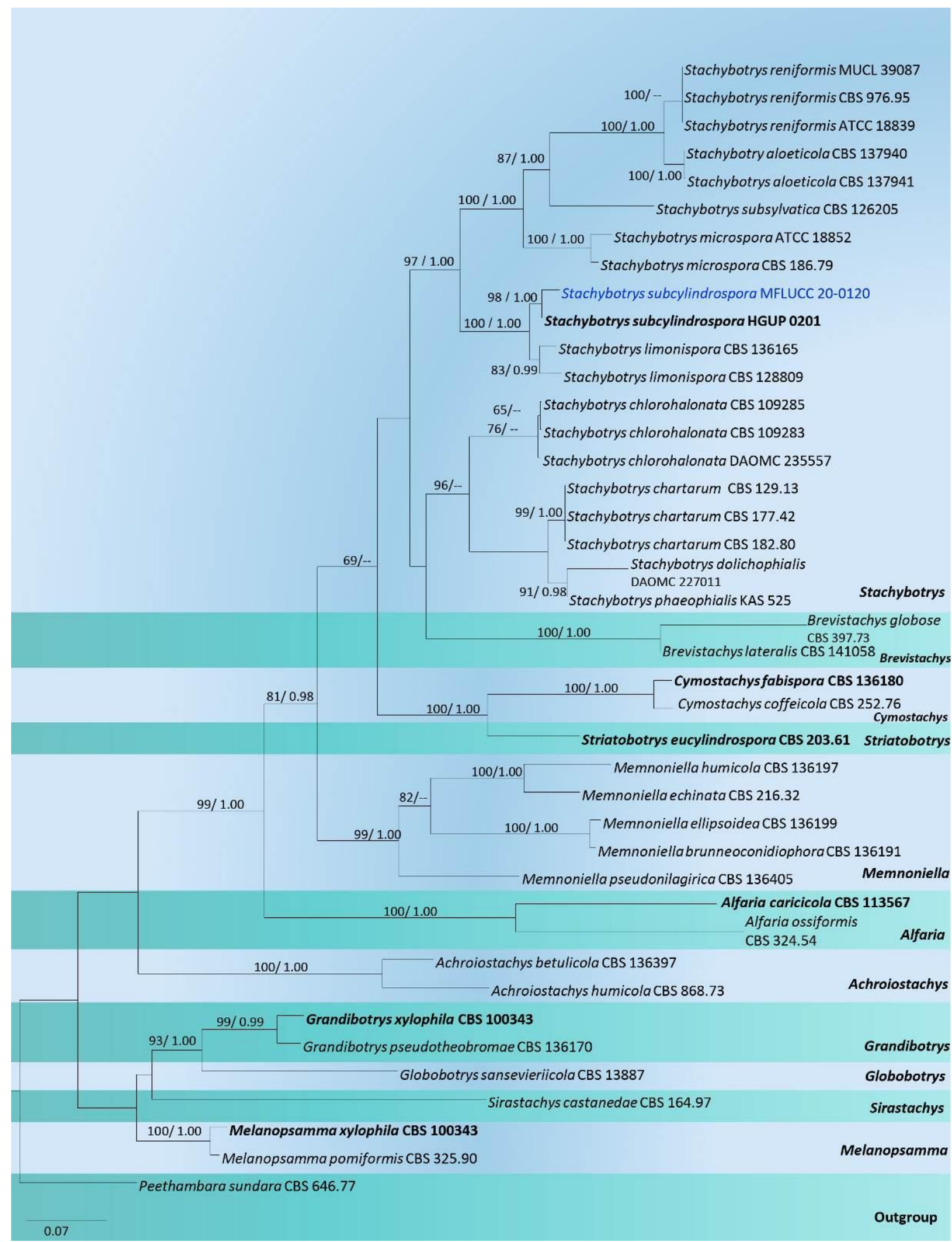

Fig. 2 - Maximum likelihood tree revealed by RAxML from an analysis of combined cmdA -ITStub2 matrix of Stachybotryaceae showing the phylogenetic position of Stachybotrys subcylindrospora (MFLUCC 20-0120). ML bootstrap supports equal to or greater than $60 \%$ and Bayesian posterior probabilities (PP) equal to or greater than 0.95 are indicated at the nodes as (ML/PP). The tree is rooted with Peethambara sundara (CBS 646.77). The ex-type strains are in bold and the new isolate of this study is in blue. The scale bar represents the expected number of nucleotide substitutions per site. 


\section{Taxonomy}

Beltraniella fertilis Heredia, R.M. Arias, M. Reyes \& R.F. Castañeda, Fungal Diversity 11: 100 (2002)

Index Fungorum number: IF489903; Faces of fungi number: FoF 03632

Fig. 3

Colonies on PDA pale white, reaching a diam. of $2-3 \mathrm{~cm}$ in 4 days at $25^{\circ} \mathrm{C}$, flat and circularshaped, pale brown, smooth at surface and produce highly branched melanized hyphae with brownish exudates in old cultures, after 16 weeks, with conidiophores forming on the mycelium; reverse light yellow to dark brown. Sexual morph: Undetermined. Asexual morph: Hyphomycetous. Mycelium mostly immersed in the substratum, composed of septate, branched subhyaline hyphae. Setae numerous, erect, straight or flexuous, unbranched, single or in small groups, thick-walled, verrucose, dark brown at the base, paler at apex, 61.7-149.8 $\mu \mathrm{m}$ long, 2.5-7 $\mu \mathrm{m}$ wide $(\bar{x}=113 \times 4 \mu \mathrm{m}, \mathrm{n}=30)$ at the base, tapering to a pointed apex. Conidiophores macronematous, sometimes setiform; single, straight, septate, partly verrucose, thick-walled to smooth-walled, 6.4-91.5 $\mu \mathrm{m}$ long, 2.3-6.5 $\mu \mathrm{m}$ wide $(\bar{x}=37 \mu \mathrm{m} \times 3.4, \mathrm{n}=30)$, sometimes branched at the apical region, dark brown to sub hyaline at the swollen base, paler and slightly tapering towards a pointed apex. Conidiogenous cells holoblastic, monoblastic to polyblastic, integrated, terminal. Conidia solitary to aggregated, acrogenous, simple, dry, straight, smooth, thin-walled, biconic, turbinate to pyriform, rostrate to pointed at proximal end, rounded at distal end, hyaline to sub hyaline, $5-15 \mu \mathrm{m}$ long, $2-6.5 \mu \mathrm{m}$ wide $(\bar{x}=10.11 \times 3.97 \mu \mathrm{m}, \mathrm{n}=30)$ in the broadest part.

Distribution - Atlantic forests, Brazil, Mexico, Thailand

Known hosts - Dead leaves of Mangifera indica and Parinari alvimii

Material examined - Thailand, Chiang Mai Province, Mae Tang district, Ban Pa Deng, Mushroom Research Center, N 1907' 13.7', E 98 43' 52,9”, $905 \mathrm{~m}$, in forest soil (dominated by Dipterocarpaceae), 20 ${ }^{\text {th }}$ March 2019, Erandi Yasanthika, Erscm11 (MFLU 20-0506), living culture MFLUCC 20-0119.

Notes - Beltraniella fertilis was introduced by Heredia et al. (2002) based on morphological characteristics. The sequence data for this species was provided by Lin et al. (2017b) for strains MFLUCC 17-2136, MFLUCC 17-2137 and MFLUCC 17-2138 isolated from decaying leaves collected in Thailand. Most of Beltraniella strains in GenBank have only ITS and LSU sequence data. In the combined phylogenetic tree (LSU-ITS) of Beltraniaceae (Fig. 1), species delineation within Beltraniella has low bootstrap support. This low support can be due to the lack of proteincoding gene sequences, or else B. fertilis may be a species complex (Jeewon \& Hyde 2016). Existing strains of Beltraniella fertilis (MFLUCC 17-2136, MFLUCC 17-2137, MFLUCC 17-2138 and MFLUCC 19-0487) and our isolate (MFLUCC 20-0119) clustered with good support (ML = $82 \%, \mathrm{PP}=0.95$ ) in the phylogenetic tree. Our strain (MFLU 20-0506) is similar to the holotype of B. fertilis (CB712XAL) in having numerous setae in the colony, setiform conidiophores and solitary to aggregated, acrogenous, simple, dry, straight, smooth, thin-walled, biconic, turbinate to pyriform, rostrate to pointed at the proximal end, rounded at the distal end, hyaline to sub-hyaline conidia. However, compared to Heredia et al. (2002) and Lin et al. (2017b), the size of conidia is different and conidial formation from separating cells was not observed in our study. These morphological variations can be resulted due to the effects of different environmental conditions (Francisco et al. 2019). Based on both morphological characteristics and multigene phylogenetic analysis, we report this collection as B. fertilis from forest soils in Thailand.

Stachybotrys subcylindrospora C.Y. Jie, Y.L. Jiang, D.W. Li, E.H.C. McKenzie \& Yong Wang bis, Mycological Progress 12 (4): 695 (2012)

Fig. 4

Index Fungorum Number: IF821464; Facesoffungi number: FoF08728

Colonies on PDA, initially with abundant white to brownish aerial mycelium, mostly superficial, immersed at margins, forming lobate shaped edge reaching a diam. of 2-3 cm in 7 days at $25^{\circ} \mathrm{C}$; becoming amber to brownish with wrinkled granulated surface. After 3 weeks, conidiophores forming on the aerial mycelium becoming slimy with grey to black conidial masses; 
reverse brownish center and amber at periphery. Sexual morph: Undetermined. Asexual morph: Hyphomycetous. Conidiophores macronematous, mononematous, single or in groups, determinate, thin-walled, simple to irregularly branched, erect to slightly curved, hyaline to sub-hyaline, uniseptate, smooth, 22-70 $\mu \mathrm{m}$ long, 2-6 $\mu \mathrm{m}$ wide $(\bar{x}=50 \times 4 \mu \mathrm{m}, \mathrm{n}=30)$ with curved base, terminating in phialidic conidiogenous cells. Phialides in groups of 3-6 on the apices of conidiophores, discrete, clavate to subclavate, hyaline, smooth, $6-11 \mu \mathrm{m}$ long and $2-6 \mu \mathrm{m}$ wide $(\bar{x}$ $=9 \times 5 \mu \mathrm{m}, \mathrm{n}=30$ ), with conspicuous collarettes. Conidia acrogenous, aggregated in slimy masses, aseptate, cylindrical or subcylindrical, thick-walled, truncated at base, rounded at the apex, hyaline when young, becoming subhyaline to brown at maturity, verruculose, 6-11 $\mu \mathrm{m}$ long, 4-6 $\mu \mathrm{m}$ wide $(\bar{x}=10 \times 4.5 \mu \mathrm{m}, \mathrm{n}=30)$; young conidia bear delicate irregular to circular striations and become $1-$ 3 guttulate when mature.

Distribution - Hainan Province in China and Thailand

Known hosts - Tropical primeval rain forest soil

Material examined - Thailand, Chiang Mai Province, Mae Tang district, Ban Pa Deng, Mushroom Research Center, N 19 $07^{\circ}$ ' 13.7', E 98 43' 52,9”, $905 \mathrm{~m}$, in forest soil (dominated by Dipterocarpaceae), 20 ${ }^{\text {th }}$ March 2019, Erandi Yasanthika, Er202 (MFLU 20-0505); living culture MFLUCC 20-0120

Notes - In the multigene phylogenetic analysis (Calmodulin-ITS- $\beta$-tubulin) of Stachybotrys, our strain (MFLUCC 20-0120) grouped with the type strain of S. subcylindrospora (HGUP 0201). Our isolate is morphologically similar to S. subcylindrospora (HGUP 0201) in having cylindrical conidia. However, conidia of S. subcylindrospora (HGUP 0201) have irregular striations on the surface (Jie et al. 2013), while immature conidia of our strain (MFLUCC 200120) bears circular to irregular surface striations and 1-3 guttules at maturity. These changes may be due to an adaptation to withstand diverse environmental stresses (Francisco et al. 2019). Based on both morphological characteristics and multigene phylogenetic analysis, we report our collection (MFLUCC 20-0120) as S. subcylindrospora from forest soils in Thailand.

\section{Discussion}

Beltraniella fertilis recorded on dead leaves of Mangifera indica and Parinari alvimii (Heredia et al. 2002, Magalhães et al. 2011). Beltraniella fertilis has been recorded from both living plants and dead or decomposing leaves (Heredia et al. 2002, Marques et al. 2007). Therefore, we presume that $B$. fertilis can switch its life mode from endophytic to saprobic based on the availability of nutrients (Promputtha et al. 2010). Lin et al. (2017b) recorded this species on dead leaves from Thailand and provided molecular data for the first time. We report on B. fertilis from forest soils in Thailand for the first time. In this study, B. fertilis was isolated by soil dilution plating method. The sporulation barely occurred on PDA $\left(25^{\circ} \mathrm{C}\right)$ as very few spores were formed even after 3-4 months of incubation.

Beltraniella fertilis and B. botryospora are morphologically similar in having two types of conidiophores (long setiform and short non-setiform), polyblastic conidiogenesis, separating cells and turbinate conidia (Shirouzu et al. 2010). However, B. fertilis has short setae and narrower conidia that can be distinguished from B. botryospora (Lin et al. 2017b).

Stachybotrys subcylindrospora was previously reported from tropical primeval rain forest soil of Hainan Province in China (Jie et al. 2013). Based on phylogenetic inference of ITS sequence data by Jie et al. (2013) and Lombard et al. (2016), S. subcylindrospora is closely related to S. limonispora, S. sansevieriae and S. zeae. However, this is the first study that uses combined cmdA, ITS and tub2 sequence data for $S$. subcylindrospora, which further validates the phylogenetic placement of the taxa within the genus.

Stachybotrys limonispora is phylogenetically adjacent to S. subcylindrospora, and both species reported from the soil. However, $S$. limonispora is morphologically distinct from $S$. subcylindrospora in having limoniform conidia (Lombard et al. 2016). Jie et al. (2013) mentioned that $S$. subcylindrospora has cylindrical conidia similar to $S$. eucylindrospora and $S$. longispora. However, $S$. longispora contains smooth conidia that are different from $S$. 
subcylindrospora. Conidia in $S$. eucylindrospora contain longitudinal striations, while $S$. subcylindrospora shows circular to irregular striations in immature conidia and 1-3 guttules when mature. This is the first geographical record of S. subcylindrospora from forest soils of Thailand.
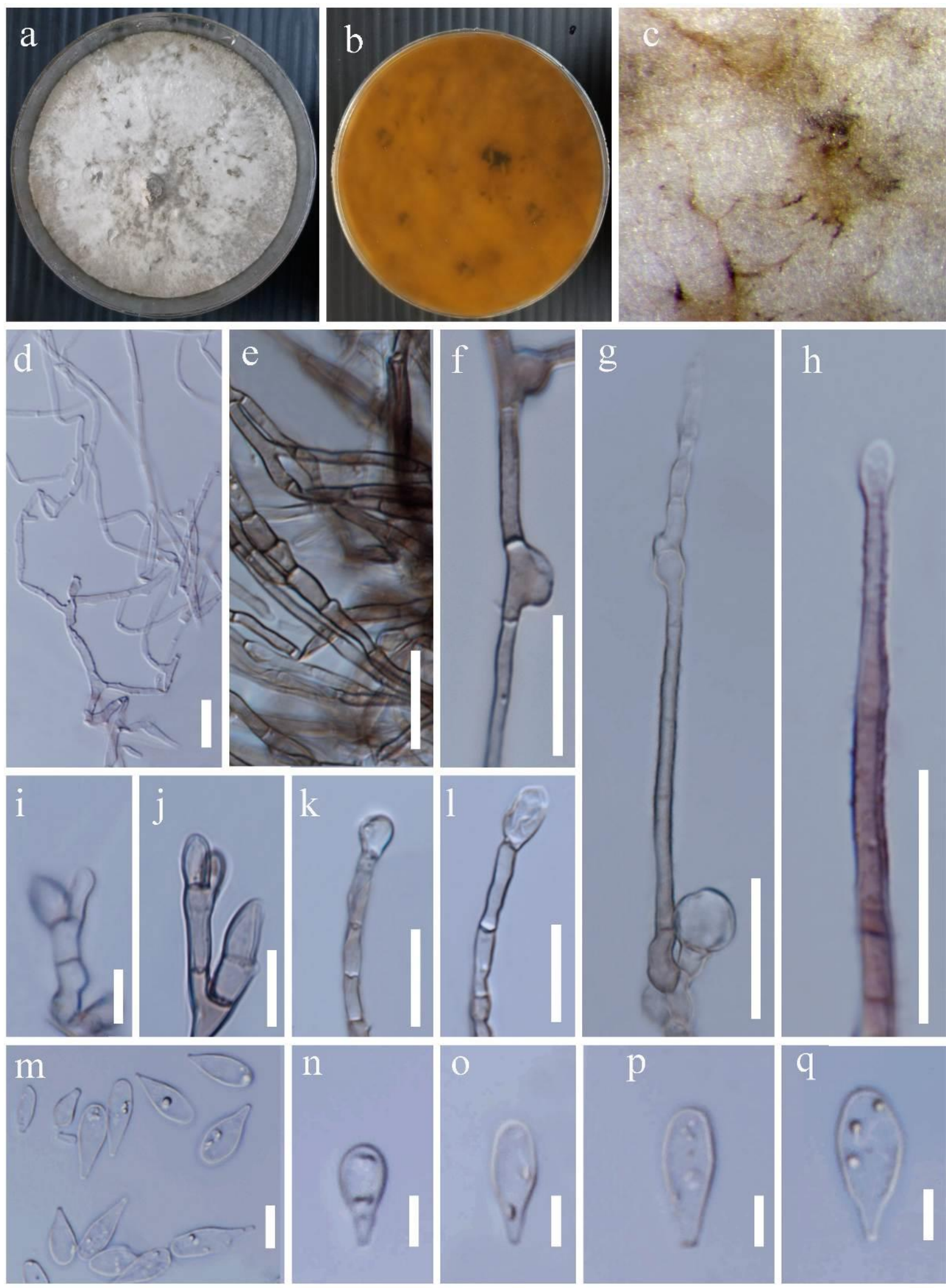

Fig. 3 - Beltraniella fertilis (MFLUCC 20-0119). a Mature colony on PDA after 16 weeks with the sporulation. b Reverse of the colonies on PDA after 16 weeks. c Sporulation of the colony with conidial attachments on the mycelium. $\mathrm{d}$ Immature aseptate hyphae. e Mature pigmented, septate 
hyphae. $\mathrm{f}$ Chlamydospores on the mycelium. $g$ Verrucose pigmented setae arising from the mycelium. $\mathrm{h}$ Conidiogenesis on the setae. $\mathrm{i}-\mathrm{l}$ Conidiogenesis on the conidiophore. $\mathrm{m}-\mathrm{q}$ Conidia. Scale bars: $\mathrm{g}=25 \mu \mathrm{m} d, \mathrm{~h}, \mathrm{i}=20 \mu \mathrm{m}, \mathrm{e}, \mathrm{f}, \mathrm{j}, \mathrm{k}, \mathrm{l}, \mathrm{m}=10 \mu \mathrm{m}, \mathrm{n}-\mathrm{q}=5 \mu \mathrm{m}$.
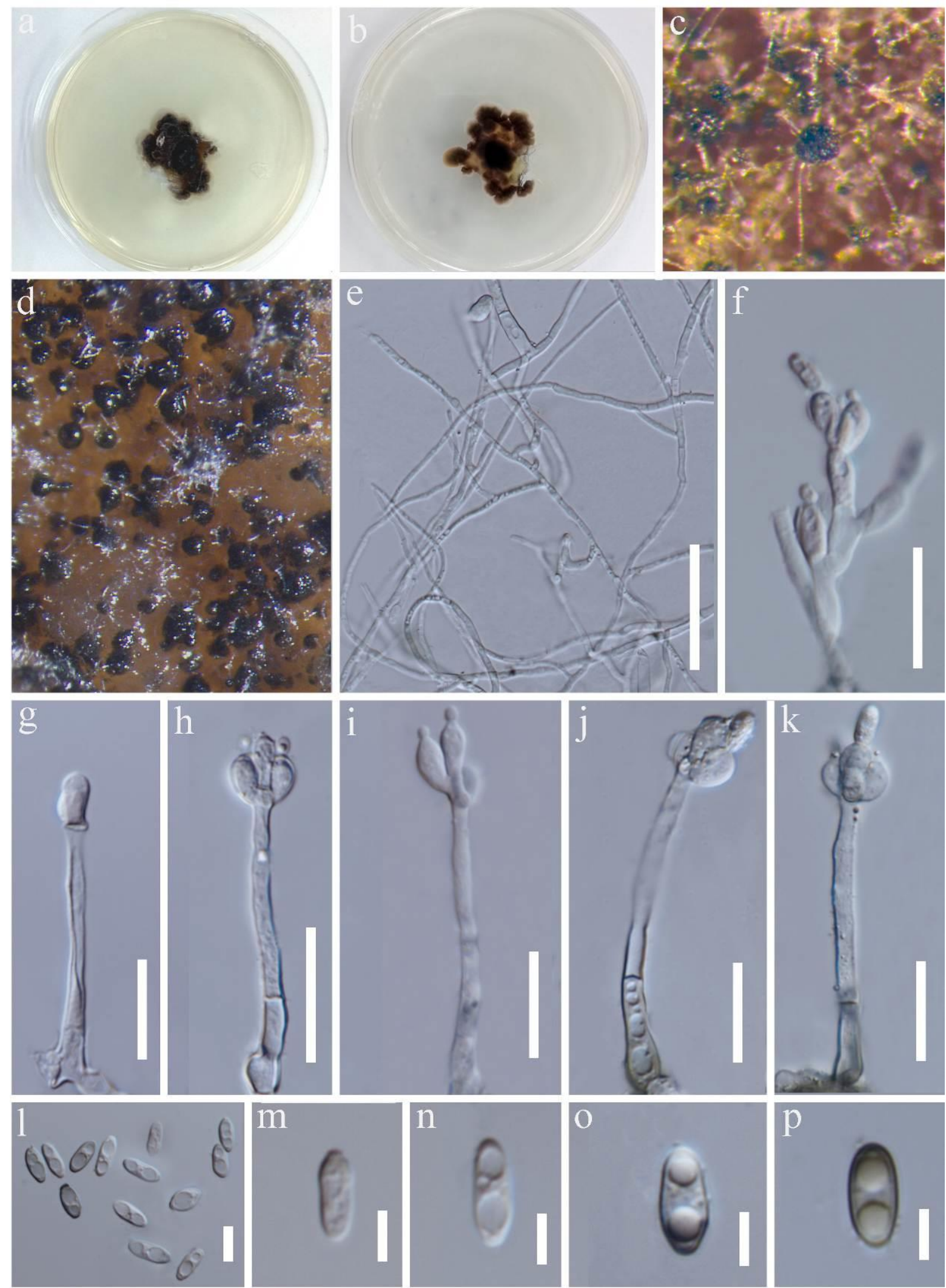

Fig. 4 - Stachybotrys subcylindrospora (MFLUCC 20-0120). a Mature colony on PDA after 3 weeks with the sporulation. b Reverse of the colonies on PDA after 3 weeks. c, d Sporulation of the colony appear grey to black with conidial attachments on the mycelium. e Mycelium with aseptate 
hyphae. $\mathrm{f}-\mathrm{k}$ Conidiogenesis cells and conidia attached on the conidiophore. $1-\mathrm{p}$ Conidia. Scale bars: $\mathrm{e}-\mathrm{k}=20 \mu \mathrm{m}, \mathrm{l}=10 \mu \mathrm{m}, \mathrm{m}-\mathrm{p}=5 \mu \mathrm{m}$

\section{Acknowledgements}

This work is supported by the Thailand Research Fund "Impact of climate change on fungal diversity and biogeography in the Greater Mekong Subregion" (grant no: RDG6130001). Samantha C. Karunarathna thanks the CAS President's International Fellowship Initiative (PIFI) young staff under the grant number: 2020FYC0002 and the National Science Foundation of China (NSFC) project code 31750110478 for funding this work. Peter E. Mortimer thanks the National Science Foundation of China grants: 41761144055 and 41771063. Dhanushka Wanasinghe would like to thank CAS President's International Fellowship Initiative (PIFI) for funding his postdoctoral research (number 2019PC0008) and the $64^{\text {th }}$ batch of China Postdoctoral Science Foundation (grant no.: Y913083271).

\section{References}

Amma S, Toju H, Wachrinrat C, Sato H et al. 2018 - Composition and diversity of soil fungi in Dipterocarpaceae-Dominated seasonal tropical forests in Thailand. Microbes and Environments 33, 135-143.

Aziz NH, Zainol N. 2018 - Isolation and identification of soil fungi isolates from forest soil for flooded soil recovery. IOP Conference Series: Materials Science and Engineering 342.012028.

Bisby G. 1943 - Stachybotrys. Transactions of the British Mycological Society 26, 133-143.

Bisby G. 1945 - Stachybotrys and Memnoniella. Transactions of the British Mycological Society 28, 11-12.

Bridge P, Spooner B. 2001 - Soil fungi: diversity and detection. Plant and soil 232, 147-154.

Carbone I, Kohn LM. 1999 - A method for designing primer sets for speciation studies in filamentous ascomycetes. Mycologia 91, 553-556.

Castañeda-Ruiz RF, Cano J, Guarro J. 1996 - Notes on conidial fungi. VII. Two new species of Beltraniella from Cuba. Mycotaxon 58, 243-251.

Corda ACJ. 1837 - Icones fungorum hucusque cognitorum 1, 1-32.

Crous PW. Shivasr G, Quaedvliegw, Van Derbank M et al. 2014 - Fungal Planet description sheets: 214-280. Persoonia 32, 184-306.

Dos Santos MVO, Barbosa FR, Magalhães DMA, Luz EDMN, Bezerra JL. 2014 - Beltraniella species associated with leaf litter of the Atlantic Forest in southern Bahia, Brazil. Mycotaxon $129,1-6$.

Duong LM, Mckenzie EHC, Lumyong S. Hyde KD. 2008 - Fungal succession on senescent leaves of Castanopsis diversifolia in Doi Suthep-Pui National Park, Thailand. Fungal Diversity 30, 23- 36.

Ellis MB. 1971 - Dematiaceous Hyphomycetes. Commonwealth Mycological Institute, Kew, Surrey, England.

Ellis MB. 1976 - More Dematiaceous Hyphomycetes. Commonwealth Mycological Institute, Kew, Surrey, England.

Francisco CS, Ma X, Zwyssig MM. 2019 - Morphological changes in response to environmental stresses in the fungal plant pathogen Zymoseptoria tritici. Scientific Reports 9, 9642.

Glass NL, Donaldson G. 1995 - Development of primer sets designed for use with PCR to amplify conserved genes from filamentous ascomycetes. Applied and Environmental Microbiology $61,1323-1330$.

Goh TK, Hyde KD. 1996 - Biodiversity of freshwater fungi. Journal of Industrial Microbiology 17, 328-345.

Groenewald M, Groenewald JZ, Crous PW. 2005 - Distinct species exist within the Cercospora apii morphotype. Phytopathology 95, 951-959. 
Gusmão LF, Grandi RA, Milanez AI. 2000 - A new species of Beltraniopsis from Brazil, with a key to the known species. Mycological Research 104, 251-253.

Hall TA. 1999 - Bioedit: A user-friendly biological sequence alignment editor and analysis program for windows 95/98/Nt. Nucleic Acids Symposium Series 4, 95-98.

Heredia G, Arias RM, Reyes M, Castañeda-Ruíz R. 2002 - New anamorph fungi with rhombic conidia from Mexican tropical forest litter. Fungal Diversity 11, 99-107.

Hodges CS, Barr ME, 1971 - A new species of Pseudomassaria and its Beltraniella conidial state. Mycologia 63, 562-566.

Huelsenbeck JP, Ronquist F. 2001- MRBAYES: Bayesian inference of phylogenetic trees. Bioinformatics. 17, 754-755.

Hyde KD, Norphanphoun C, Maharachchikumbura SSN, Bhat DJ et al. 2020 - Refined families of Sordariomycetes. Mycosphere 11, 305-1059.

Index Fungorum. 2020 - Available from: http://www.indexfungorum.org/names/names.asp (Accessed on August 6, 2020).

Jaklitsch W, Gardiennet A, Voglmayr H. 2016 - Resolution of morphology-based taxonomic delusions: Acrocordiella, Basiseptospora, Blogiascospora, Clypeosphaeria, Hymenopleella, Lepteutypa, Pseudapiospora, Requienella, Seiridium and Strickeria. Persoonia 37, 82-105.

Jayasiri SC, Hyde KD, Ariyawansa HA, Bhat J et al. 2015 - The faces of fungi database: fungal names linked with morphology, phylogeny and human impacts. Fungal Diversity 74, 3-18.

Jeewon R, Hyde KD. 2016 - Establishing species boundaries and new taxa among fungi: recommendations to resolve taxonomic ambiguities. Mycosphere 7, 1669-1677.

Jie CY, Geng K, Jiang Y-L, Xu JJ 2013 - Stachybotrys from soil in China, identified by morphology and molecular phylogeny. Mycological Progress 12, 693-698.

Jong SC, Davis EE. 1976 - Contribution to the knowledge of Stachybotrys and Memnoniella in culture. Mycotaxon 3, 409-485.

Katoh K, Misawa K, Kuma K, Miyata T. 2002 - MAFFT: a novel method for rapid multiple sequence alignment based on fast fourier transform. Nucleic Acids Research 30, 3059-3066.

Khuna S, Suwannarach N, Kumla J, Meerak J et al. 2019 - Apophysomyces thailandensis (Mucorales, Mucoromycota), a new species isolated from soil in northern Thailand and its solubilization of non-soluble minerals. MycoKeys 45, 75 -92.

Kirk PM. 1981 - New or interesting microfungi. III, A preliminary account of micro fungi colonizing Laururs nobilis leaf litter. Transactions of the British Mycological Society 77, 457- 473 .

Lechat C, Hairaud M, Lesage-Meessen L. 2013 - Stachybotrys oleronensis Lechat, Hairaud \& Lesage-Messen, sp. nov., Fungal Planet 208. Persoonia 31, 282-283

Lee SH, Park HS, Nguyen TTT, Lee HB. 2019 - Characterization of three species of Sordariomycetes isolated from freshwater and soil samples in Korea. Mycobiology 47, 20 30.

Lin CG, Dai DQ, Bhat DJ, Hyde KD et al. 2017a - Subsessila turbinata gen. et. sp. nov. (Beltraniaceae), a Beltrania - like fungus from Thailand. Mycological Progress 16, 393-401.

Lin CG, Hyde KD, Lumyong S, Mckenzie EHC. 2017b - Beltrania-like taxa from Thailand. Cryptogamie, Mycologie 38, 301-319

Lin CG, Mckenzie E, Bhat DJ, Ran SF et al. 2016 - Stachybotrys - like taxa from karst areas and a checklist of Stachybotrys - like species from Thailand. Mycosphere 7, 1273-1291.

Lombard L, Houbraken J, Decock C, Samson R et al. 2016 - Generic hyper-diversity in Stachybotriaceae. Persoonia 36, 156-246.

Magalhães DMA, Luz EDMN, Magalhães AF, Santos Filho LPdos et al. 2011 - Riqueza de fungos anamorfos na serapilheira de Manilkara maxima, Parinari alvimii e Harleyodendron unifoliolatum na Mata Atlântica do Sul da Bahia. Acta Botânica Brasílica 25, 899-907.

Marques MFO, Barbosa FR, Gusmão LFP, Castañeda-Ruiz RF, Maia LC. 2007 - Conidial fungi from the semi-arid Caatinga biome of Brazil. Cubasina microspora sp. nov., a note on C. albofusca, and some new records for South America. Mycotaxon 102, 17-23. 
Miller MA, Pfeiffer W, Schwartz T. 2010 - Creating the CIPRES science gateway for inference of large phylogenetic trees. Proceedings of the gateway computing environments workshop (GCE), November 14, 2010, New Orleans, Louisiana 1-8.

Pangging M, Nguyen TTT, Lee HB. 2019 - New records of four species belonging to Eurotiales from soil and freshwater in Korea. Mycobiology 47, 154-164.

Pinruan U, McKenzie EH, Jones EG, Hyde KD. 2004 - Two new species of Stachybotrys, and a key to the genus. Fungal Diversity 17, 145-157.

Pirozynski KA. 1963 - Beltrania and related genera. Mycological Papers 90, 1-37.

Promputtha I, Hyde KD, McKenzie EHC, Peberdy JF, Lumyong S. 2010 - Can leaf degrading enzymes provide evidence that endophytic fungi becoming saprobes? Fungal Diversity 41, 8999.

Rambaut A. 2010 - FigTree. Tree figure drawing tool version 1.3.1, Institute of Evolutionary Biology, University of Edinburgh. Available from: http://tree.bio.ed.ac.uk/software/figtree/ (Accessed on April 8, 2020).

Rannala B, Yang Z. 1996 - Probability distribution of molecular evolutionary trees: a new method of phylogenetic inference. Journal of Molecular Evolution 43, 304-311.

Sakayaroj J, Phongpaichit S, Jones EBG. 2005 - Viability and biodiversity of freshwater hyphomycetes in foam at Ton Nga Chang. Wildlife - Sanctuary, Songkhla, southern Thailand. Fungal Diversity 18, 135-145.

Seifert KA, Morgan-Jones G, Gams W, Kendrick B. 2011 - The genera of hyphomycetes. Utrecht, The Netherlands, CBS - KNAW Fungal Biodiversity Centre.

Shi L, Dossa GG, Paudel E, Zang H et al. 2019 - Changes in fungal communities across a forest disturbance gradient. Applied and Environmental Microbiology 85, e00080-19.

Shirouzu T, Hirose D, Tokumasu S, To-anun C, Maekawa N. 2010 - Host affinity and phylogenetic position of a new anamorphic fungus Beltraniella botryospora from living andfallen leaves of evergreen oaks. Fungal Diversity 43, 85-92.

Stamatakis A, Hoover P, Rougemont J. 2008 - A rapid bootstrap algorithm for the RAxML web servers. Systematic Biology 57, 758-771.

Subramanian CV. 1952 - Fungi Imperfecti from Madras - iii. Proceedings of The Indian Academy of Sciences - Section B36, 223-228.

Taylor DL, Sinsabaugh RL. 2015 - The soil fungi: occurrence, phylogeny, and ecology. Soil microbiology, ecology, and biochemistry 4, 77-109.

Tedersoo L, Bahram M, Põlme S, Kõljalg U et al. 2014. Global diversity and geography of soil fungi. Science 346(6213), 1256688/1-1256688/10.

Thongkantha S, Lumyong S, McKenzie EHC, Hyde KD. 2008 - Fungal saprobes and pathogens occurring on tissues of Dracaena lourieri and Pandanus spp. in Thailand. Fungal Diversity 30, 149-169.

Vilgalys R, Hester M. 1990 - Rapid genetic identification and mapping of enzymatically amplified ribosomal DNA from several Cryptococcus species. Journal of Bacteriology 172, 4238-4246.

Wang Y, Hyde K, Mckenzie E, Jiang YL et al. 2015 - Overview of Stachybotrys (Memnoniella) and current species status. Fungal Diversity 71, 17-83.

Wei X, Wang X, Cao P, Gao Z et al. 2020 - Microbial community changes in the rhizosphere soil of healthy and rusty Panax ginseng and discovery of pivotal fungal genera associated with rusty roots. BioMed Research International 2020, 1-13

White TJ, Bruns T, Lee SJWT, Taylor JL. 1990 - Amplification and direct sequencing of fungal ribosomal RNA genes for phylogenetics. PCR protocols: a guide to methods and applications $18,315-322$.

Whitton SR, McKenzie EHC, Hyde KD. 2001 - Microfungi on the Pandanaceae: Stachybotrys, with three new species. New Zealand Journal of Botany 39, 489-499.

Wu YM, Zhang TY. 2010 - Two new species of Stachybotrys from soil. Mycotaxon 114, 459-462.

Wijayawardene NN, Hyde KD, Al-Ani LKT, Tedersoo L et al. 2020 - Outline of Fungi and Fungus-like Taxa. Mycosphere 11, 1060-1456. 
Wu YT, Wubet T, Trogisch S, Both S et al. 2013 - Forest age and plant species composition determine the soil fungal community composition in a Chinese subtropical forest. PLoS One 8 , e66829.

Yang JC, Insam H. 1991 - Microbial biomass and relative contributions of bacteria and fungi in soil beneath tropical rain forest, Hainan Island, China. Journal of Tropical Ecology 7, 385393.

Zhaxybayeva O, Gogarten JP. 2002 - Bootstrap, Bayesian probability and maximum likelihood mapping: exploring new tools for comparative genome analyses. Biomed central genomics 3 , $1-4$. 